of the commodity the problem is linear; but if the costs are brokerage fees proportional to the amount bought or sold the problem is non-linear. Optimal operating policies are determined in each case. Another problem deals with the allocation of $n$ tasks to $m$ machines, where the machines are ordered in terms of increasing capability and the tasks in order of increasing difficulty. A third problem-directly in the field of inter-industry economics-is solved by a method which was originally applied to the problem of resource allocation in under-developed countries.

Mathematics has by now invaded in force the social sciences. The vigour with which various classes of problems in economics, for example, are being attacked mathematically is quite surprising. This situation implies an increasing divergence between what one might call the verbal or linguistic economist and the econometrician, who deals, so far as possible, with measurable concepts. The book under review is certainly meant for the latter-in fact it will probably only be understood by the mathematician interested in economics rather than the economist who would like to understand the workings of mathematics within his subject.

L. S. GODDARD

\section{MANAGEMENT IN THE UNITED STATES AND THE U.S.S.R.}

The Red Executive

A Study of the Organization Man in Russian Industry. By Dr. David Granick. Pp. 334. (London: Macmillan and Co., Ltd., 1960.) 21s. net.

$\mathrm{N}$ amalgam of wide reading, many personal discussions and actual visits to a variety of industries inside the U.S.S.R. and the United States has enabled Dr. D. Granick of the University of Wisconsin to provide a great deal of comparative information about Russian and American management which hitherto has been subject to little more than speculation.

During his investigations Granick set out to determine the educational background of the managers, the pressures and incentives which govern their lives, the tasks before them and how the factories and social environment of the U.S.S.R. differ from those in the United States. For the British student, at least, the book is most satisfying and worthy of recommendation to many readers. The most striking of the findings are those which show that the similarities between the Russian and American management greatly outnumber the differences and, indeed, link them more closely than American and British managers.

The main differences stem from the nature of each country's economy. In the U.S.S.R. the marketing manager does not exist; everything produced can be sold. Salesmanship, advertising and product design to meet competition and make last year's model obsolete, which are major American pastimes, do not exist in the U.S.S.R. Their problem is the getting and allocation of raw material, and the American purchasing officer is replaced by a procurement official.

A major difference might appear to be the place of the trade unions. Whereas in the United States the unions are reputed for their ability to drive hard bargains and, sometimes, disrupt production, in the U.S.S.R. the trade unions are imagined to be apostles of productivity and essential props for management. This may well be, but those familiar with the politically backed works commune would support Granick's statement that the American manager has little cause for grumbling compared with the Russian. A surprising difference is that the Russian manager is much more prepared to try out new ideas than his American counterpart. Granick believes that this may spring from the much more "theoretic" nature of the Russian training.

Among the many similarities of the Russian and American managers, the most striking (and from the British point of view the most challenging) lies in their educational backgrounds. In the U.S.S.R. the majority of managers get full-time education up to university level ; in the United States little more than half are college-trained. In the U.S.S.R. the majority have engineering degrees; in the United States almost half the college-trained managers have general arts degrees. The American preoccupation for the "rounded" man is bound up with the fact that students are free to choose courses for themselves. This is also true of the U.S.S.R., but the courses made available are circumscribed by the needs of the economy.

The American graduate business training schools are largely missing in the U.S.S.R., which professedly believes in the value of manual work in introducing graduates to industry. The differences are not so great, however, because the Russian engineering graduates take a postgraduate diploma which necessitates involvement in an industrial organization. Another point of similarity is that, although the position is hardening in the United States, in both countries the way to the top is still wide open to the boy of ability and application.

Many other matters emerge to make this book of absorbing interest. Russian academic authorities, for example, appear to be as hazy about Russian management practice as most American university lecturers are about what goes on in their business training schools. The echo from Britain would also resound to complaints from research workers from both sides of the Iron Curtain about the difficulties they meet in obtaining permission to study factory administration in any kind of depth.

In both countries students are encouraged to work in industry as part of their educational (sic) develop. ment. One large American university has about one-seventh of its better-off full-time students doing forty-hour-a-week-jobs. In the U.S.S.R., as in Britain, the student is expected to study full-time during university term. Before graduating to the managerial level, however, the Russian spends a considerable period as foreman or assistant. The attitude of some British university teachers to vacation work for students may need reconsideration.

Granick also deals with the size of industry in both countries, the inverse operation of Parkinson's Law in the U.S.S.R. over the past twenty years (this supports those who believe it to be based on false premises), the lack of definition of the foreman's job in the United States, U.S.S.R., and Britain, and enough related matters to make his book worth a place in libraries in many countries. He should now perform a service to British management by preparing a second volume describing the observations he has made during his year as a Fulbright Fellow in Great Britain.
T. H. HAWKINS 